\title{
PENGARUH KONSENTRASI PGPR DAN DOSIS PUPUK KALIUM TERHADAP PERTUMBUHAN DAN HASIL TANAMAN JAGUNG MANIS (Zea mays S.)
}

\author{
Effect of PGPR Concentration and Potassium Fertilizer Dosage on Growth and \\ Yield of Sweet Corn Plants (Zea mays S.).
}

\author{
Hilman Sopiandi ${ }^{1)}$, Dadi Nurdiana ${ }^{2}$, dan Isna Tustiyani ${ }^{2}{ }^{2 *}$ \\ 1) Alumni Program Studi Agroteknologi Fakultas Pertanian Universitas Garut \\ ${ }^{2)}$ Staf Pengajar Program Studi Agroteknologi Fakultas Pertanian Universitas Garut \\ *Email : isnatustiyani@gmail.com
}

\begin{abstract}
ABSTRAK
Penggunaan bahan organik dalam budidaya jagung dapat meningkatkan produktivitas tanaman. Sebagai contohnya menggunakan bahan organik yang berasal dari daerah sekitar, yaitu PGPR. Penelitian ini bertujuan untuk mengetahui pengaruh konsentrasi PGPR dan dosis pupuk kalium terhadap pertumbuhan dan hasil tanaman jagung. Percobaan dilaksanakan pada bulan Januari sampai Maret 2019 di kebun percobaan Balai Pengembangan Benih Padi dan Palawija Kecamatan Karangpawitan. Penelitian menggunakan Rancangan Acak Kelompok (RAK) pola faktorial 4×4 dengan 2 kali ulangan. Faktor perlakuan pertama adalah Konsentrasi PGPR (P) dengan empat taraf, yaitu : $\mathrm{p}_{0}=$ Kontrol, $\mathrm{p}_{1}=10 \mathrm{ml} / \mathrm{l}, \mathrm{p}_{2}=20 \mathrm{ml} / \mathrm{l}$, dan $\mathrm{p}_{3}=30 \mathrm{ml} / \mathrm{l}$. Faktor perlakuan kedua adalah dosis Pupuk Kalium (K) dengan empat taraf yaitu : $\mathrm{k}_{0}=$ Kontrol, $\mathrm{k}_{1}=50 \mathrm{~kg} / \mathrm{ha}(0.94 \mathrm{gr} / \mathrm{tan}), \mathrm{k}_{2}=$ $75 \mathrm{~kg} / \mathrm{ha}(1.41 \mathrm{gr} / \mathrm{tan})$, dan $\mathrm{k}_{3}=100 \mathrm{~kg} / \mathrm{ha}(1.88 \mathrm{gr} / \mathrm{tan})$. Hasil penelitian menunjukkan bahwa terjadi interaksi antara waktu konsentrasi PGPR dan dosis pupuk kalium terhadap pertumbuhan dan hasil tanaman jagung. Secara mandiri perlakuan konsentrasi PGPR dan dosis kalium tidak memberikan pengaruh yang berbeda nyata pada semua parameter perlakuan..
\end{abstract}

Kata kunci : PGPR, Pupuk Kalium, Jagung Manis.

\begin{abstract}
The use of organic materials in corn cultivation can increase crop productivity. For example, using organic materials from the surrounding area, namely PGPR. This study aimed to determine the effect of PGPR concentration and potassium fertilizer dosage on the growth and yield of corn plants. The experiment was carried out from January to March 2019 in the experimental garden of the Development Center for Rice and Palawija Seed in Kecamatan Karangpawitan. The study used a Randomized Block Design (RBD) $4 \times 4$ factorial pattern with 2 replications. The first treatment factor was the concentration of $P G P R(P)$ with four levels, namely: $p 0=$ Control, $p 1=10 \mathrm{ml} / l, p 2=20 \mathrm{ml} / l$, and $p 3=30$ $\mathrm{ml} / \mathrm{l}$. The second treatment factor is the dose of Potassium Fertilizer $(K)$ with four levels, namely: $k 0=$ Control, $\mathrm{kl}=50 \mathrm{~kg} / \mathrm{ha}(0.94 \mathrm{gr} / \mathrm{tan}), \mathrm{k} 2=75 \mathrm{~kg} / \mathrm{ha}(1.41 \mathrm{gr} / \mathrm{tan})$, and $\mathrm{k} 3$ $=100 \mathrm{~kg} / \mathrm{ha}(1.88 \mathrm{gr} / \mathrm{tan})$. The results showed that there was an interaction between the time of PGPR concentration and potassium fertilizer dosage on the growth and yield of corn plants. Independently the treatment of PGPR concentrations and potassium doses did not have a significant effect on all treatment parameters.
\end{abstract}

Keywords: PGPR, Potassium Fertilizer, Sweet Corn. 


\section{PENDAHULUAN}

Jagung manis merupakan salah satu komoditas pertanian yang disukai oleh masyarakat karena rasa yang lebih manis, mengandung karbohidrat, protein dan vitamin yang tinggi serta kandungan lemak yang rendah. Jagung manis mengandung kadar gula yang relatif tinggi, biasanya dipanen muda untuk dikonsumsi. Bagi para petani komoditas ini merupakan harapan, karena nilai jualnya yang cukup tinggi (Iskandar, 2007).

Produksi tanaman jagung pada tahun 2014 cenderung mengalami peningkatan. Produksi tanaman jagung tahun 2016 mencapai 23,58 juta ton atau meningkat 20,22\% dari tahun 2015 sebesar 19.61 juta ton, dan produksi tahun 2017 meningkat 10,39 \% menjadi 26,03 juta ton (BPS,2018). Akan tetapi import komoditas jagung manis masih dilakukan. Kementerian Pertanian mengungkapkan bahwa impor pada tahun 2018 periode Januari - Juli mencapai 330.800 ribu ton, jumlah import tersebut dirasa masih tinggi untuk komoditas jagung. Permintaan jagung manis dari tahun ke tahun semakin meningkat seiring dengan meningkatnya jumlah penduduk dan meningkatnya kebutuhan jagung baik untuk konsumsi langsung, bahan baku industri pangan dan industri pakan ternak.

Penggunaan bahan organik dalam budidaya jagung dapat meningkatkan produktivitas tanaman (Shaila dkk, 2019). Sebagai contohnya menggunakan bahan organik yang berasal dari daerah sekitar, yaitu kotoran sapi dan kotoran kelelawar. Menurut Saharan dan Nehra (2011) Plant Growth Promoting Rhizobacteria (PGPR) merupakan kelompok bakteri yang ada pada perakaran tanaman dan bersimbiosis dengan tanaman, dapat meningkatkan secara langsung atau tidak langsung tingkat kualitas pertumbuhan tanaman. Peran PGPR sebagai Biostimulants dan Bioprotectants pada tanaman. Menurut Putri $d k k$ (2013), bahwa PGPR berperan sebagai Biostimulants karena PGPR memproduksi fitohormon yang terdiri atas IAA (Indole Acetic Acid), Sitokinin dan Giberelin, sehingga PGPR berpotensi untuk meningkatkan produksi. Sedangkan Bioprotectants berarti bahwa PGPR dapat berperan dalam menekan dan menghambat perkembangan hama dan penyakit. PGPR juga berperan dalam terlaksananya pertanian ramah lingkungan melalui berbagai proses, seperti dekomposisi bahan organik, mineralisasi senyawa organik, fiksasi hara, pelarut hara, nitrifikasi dan denitrifikasi (Saraswati dan Sumarno, 2008)

Penggunaan pupuk Kalium pada tanaman jagung dianjurkan 50 sampai 100 $\mathrm{kg} / \mathrm{ha}$ yang diberikan sekaligus pada saat tanam kalau tanah mengandung cukup unsur kalium maka pupuk kalium bisa ditiadakan (Prahasta, 2009). Hasil penelitian Suryono 2009, melaporkan bahwa jagung dengan dosis kalium $60 \mathrm{~kg} / \mathrm{ha}$ menghasilkan berat tongkol tanpa klobot dan berat tongkol dengan klobot, dan bobot 1000 biji yang terbaik. Pada fase pembungaan, akumulasi hara K telah mencapai 60 - $75 \%$ dari kebutuhannya. Jika K kurang, gejalanya sering terlihat sebelum pembungaan yaitu pinggiran dan ujung daun menguning sampai kering. Hal ini terlihat terutama pada daun bawah. Pembentukan tongkol terpengaruh ujung tongkol 
bagian atas tidak penuh berisi biji tidak melekat secara kuat pada tongkol. Menurut (Setyono, 1986) Pupuk Kalium dapat berfungsi dalam proses pembentukan gula dan pati sehingga dapat membantu menambah rasa manis pada jagung manis. Menurut (Wibowo dkk., 2017) pupuk $\mathrm{KCl} 200 \mathrm{Kg} / \mathrm{Ha}$ mampu meningkatkan nilai kadar gula jagung manis mencapai $17^{\circ}$ Brix, sehingga perlu dilakukan penelitian mengenai pengaruh pupuk Kalium terhadap pertumbuhan dan hasil tanaman jagung manis.

\section{METODE PENELITIAN}

Percobaan dilaksanakan di kebun percobaan Balai Pengembangan Benih Padi dan Palawija Kecamatan Karangpawitan yang terletak pada ketinggian $+715 \mathrm{~m}$ dpl dan dilaksanakan pada Bulan Januari - April 2019. Tipe curah hujan berdasarkan kriteria Schmidt dan Ferguson adalah tipe curah hujan $\mathrm{C}$ yaitu agak basah. dengan rata-rata temperatur harian $28^{\circ} \mathrm{C}$.

Bahan-bahan yang digunakan dalam percobaan ini adalah benih jagung kultivar talenta, PGPR (Pseudomonas flourescens dan Bacillus subtillis), Pupuk Kalium, pupuk dasar berupa pupuk kandang, pupuk Urea, pupuk SP36 air dan pestisida. Alat-alat yang digunakan meliputi cangkul, meteran/penggaris, timbangan, oven, jaring, ajir, alat-alat tulis dan kamera.

Percobaan ini menggunakan Rancangan Acak Kelompok (RAK) dengan pola faktorial $4 \times 4$ dengan 2 kali ulangan. Faktor perlakuan pertama adalah Konsentrasi PGPR (P) dengan empat taraf, yaitu : p0 = Kontrol, p1 = $10 \mathrm{ml} / \mathrm{l}, \mathrm{p} 2=20 \mathrm{ml} / \mathrm{l}, \mathrm{p} 3=$ $30 \mathrm{ml} / \mathrm{l}$. Faktor perlakuan kedua adalah dosis Pupuk Kalium $(\mathrm{K})$ dengan empat taraf yaitu : $\mathrm{k} 0=$ Kontrol, $\mathrm{k} 1=50 \mathrm{~kg} / \mathrm{ha}(0,94 \mathrm{~g} / \tan ), \mathrm{k} 2=75 \mathrm{~kg} / \mathrm{ha}(1,41 \mathrm{~g} / \mathrm{tan}), \mathrm{k} 3=100$ $\mathrm{kg} / \mathrm{ha}(1,88 \mathrm{~g} / \mathrm{tan})$.

Parameter yang akan diamati ialah : tinggi tanaman, jumlah daun, luas daun, bobot kering tanaman, panjang tongkol, bobot tongkol per tanaman, hasil tongkol per plot, kualitas tongkol Aspek kualitas tongkol jagung bisa dilihat dari berat tongkol apabila berat $\geq 250$ gram termasuk kedalam Grade A, Jika berat 200-249 gram maka termasuk kedalam Grade B, dan jika bobot tongkol $\leq 200$ gram maka termasuk kedalam Grade C.

\section{HASIL DAN PEMBAHASAN}

\section{Tinggi Tanaman}

Hasil analisis ragam menunjukkan tidak terjadi interaksi antara dosis PGPR dan dosis kalium terhadap rata-rata tinggi tanaman jagung, dan secara mandiri juga tidak memberikan pengaruh yang nyata. Rata-rata tinggi tanaman dapat dilihat pada Tabel 1 . 
Tabel 1. Pengaruh Konsentrasi PGPR dan dosis pupuk Kalium terhadap Tinggi Tanaman

\begin{tabular}{lccc}
\hline \multirow{2}{*}{\multicolumn{1}{c}{ Perlakuan }} & \multicolumn{3}{c}{ Tinggi Tanaman $(\mathbf{c m})$} \\
\cline { 2 - 4 } & 15 HST & 30 HST & 45 HST \\
\hline Dosis PGPR & $19,15 \mathrm{a}$ & $39,13 \mathrm{a}$ & $126,98 \mathrm{a}$ \\
$\mathrm{p}_{0}(\mathrm{kontrol})$ & $20,78 \mathrm{a}$ & $40,78 \mathrm{a}$ & $129,88 \mathrm{a}$ \\
$\mathrm{p}_{1}(10 \mathrm{ml} / \mathrm{l})$ & $20,08 \mathrm{a}$ & $39,78 \mathrm{a}$ & $127,68 \mathrm{a}$ \\
$\mathrm{p}_{2}(20 \mathrm{ml} / \mathrm{l})$ & $20,25 \mathrm{a}$ & $38,35 \mathrm{a}$ & $128,05 \mathrm{a}$ \\
$\mathrm{p}_{3}(30 \mathrm{ml} / \mathrm{l})$ & & & \\
& & & \\
\hline Dosis Kalium & $18,75 \mathrm{a}$ & $39,48 \mathrm{a}$ & $125,60 \mathrm{a}$ \\
$\mathrm{k}_{0}($ Kontrol $)$ & $20,68 \mathrm{a}$ & $39,60 \mathrm{a}$ & $128,03 \mathrm{a}$ \\
$\mathrm{k}_{1}(50 \mathrm{~kg} / \mathrm{ha})$ & $19,60 \mathrm{a}$ & $38,70 \mathrm{a}$ & $126,43 \mathrm{a}$ \\
$\mathrm{k}_{2}(75 \mathrm{~kg} / \mathrm{ha})$ & $21,23 \mathrm{a}$ & $40,25 \mathrm{a}$ & $132,53 \mathrm{a}$ \\
$\mathrm{k}_{3}(100 \mathrm{~kg} / \mathrm{ha})$ & $\mathrm{a}$ & $\mathrm{a}$ & \\
\hline
\end{tabular}

Keterangan: Angka rata-rata pada kolom yang ditandai dengan huruf yang sama menunjukkan tidak berbeda nyata menurut Uji Jarak Berganda Duncan pada taraf nyata $5 \%$

Hasil analisis ragam menunjukkan berbagai taraf dosis perlakuan PGPR tidak menghasilkan perbedaan yang berbeda nyata. PGPR merupakan mikroorganisme baik yang dapat membantu dalam proses penyerapan unsur hara dalam tanah oleh tanaman. Pada penelitian pemberian pupuk N, P dan organik yang diberikan sesuai dosis supaya kebutuhannya tercukupi, yaitu pupuk urea $400 \mathrm{~kg} / \mathrm{ha}$, sp $36150 \mathrm{~kg} / \mathrm{ha}$, dan pupuk kandang sebanyak 10 ton/ha. Pemberian pupuk yang sudah sangat tinggi diduga dapat memacu pertumbuhan tanaman tanpa adanya gejala kekurangan unsur atau hambatan penyerapan. Aplikasi PGPR dari hasil analisis data memang menunjukkan perbedaan pada dosis yang lebih banyak namun diduga karena tanaman sudah maksimal dalam pertumbuhannya pemberian PGPR menjadi tidak berbeda nyata. Hal ini sejalan dengan hasil penelitian Fitrah. dkk., (2016) pemberian PGPR pada tanaman bawang merah pada umur 15, 30 dan 45 HST tidak berbeda nyata.

Hasil analisis ragam menunjukkan tidak berbeda nyata pada berbagai taraf perlakuan dosis kalium terhadap tinggi tanaman pada umur 15, 30, dan $45 \mathrm{HST}$. Hal ini diduga pupuk kalium merupakan pupuk yang tidak memacu pertumbuhan vegetatif salah satunya pertumbuhan tinggi tanaman. Pupuk yang paling berperan dalam pertumbuhan vegetatif adalah pupuk nitrogen, sehingga pertambahan dosis kalium tidak membuat berbeda nyata pada parameter tinggi tanaman. Pemupukan nitrogen merupakan pupuk yang tidak dianalisis, pemberiannya dilakukan seragam dengan dosis $400 \mathrm{~kg} / \mathrm{ha}$ selain dari pupuk urea kandungan nitrogen didapat pula dari kandungan pupuk pada tanah dan pupuk kandang yang diberikan dengan dosis 10 ton/ha pada setiap plot. Kandungan nitrogen relatif sama sehingga tinggi tanaman menjadi tidak berbeda nyata. 


\section{Jumlah Daun (helai)}

Hasil analisis ragam menunjukkan tidak terjadi interaksi antara dosis PGPR dan dosis kalium terhadap rata-rata jumlah daun tanaman jagung, dan secara mandiri juga tidak memberikan pengaruh yang nyata. Rata-rata jumlah daun tanaman dapat dilihat pada Tabel 2 .

Hasil analisis ragam dosis PGPR menunjukkan tidak berbeda nyata pada berbagai taraf perlakuan pada umur 15, 30, dan 45 HST. Hal ini sejalan dengan hasil analisis ragam pada tinggi tanaman. Pertumbuhan jumlah daun dan tinggi tanaman merupakan pertumbuhan vegetatif, pada pertumbuhan vegetatif kebutuhan serapan hara yang dibutuhkan sama yaitu pupuk nitrogen. Pemberian pupuk nitrogen yang tidak dianalisis diberikan dalam dosis yang sama yaitu $400 \mathrm{~kg} / \mathrm{ha}$ dan pupuk kandang 10 ton/ha. Pemberian pupuk yang mengandung nitrogen sebanyak itu diduga mampu memaksimalkan pertumbuhan vegetatif, sehingga pemberian mikroorganisme PGPR tidak memberikan dampak yang berbeda nyata.

Tabel 2. Pengaruh Konsentrasi PGPR dan dosis pupuk Kalium terhadap Jumlah Daun.

\begin{tabular}{lccc}
\hline \multirow{2}{*}{\multicolumn{1}{c}{ Perlakuan }} & \multicolumn{3}{c}{ Jumlah Daun (helai) } \\
\cline { 2 - 4 } & $\mathbf{1 5}$ HST & 30 HST & 45 HST \\
\hline Dosis PGPR & $5,50 \mathrm{a}$ & $6,30 \mathrm{a}$ & $7,23 \mathrm{a}$ \\
$\mathrm{p}_{0}(\mathrm{kontrol})$ & $5,45 \mathrm{a}$ & $6,43 \mathrm{a}$ & $7,75 \mathrm{a}$ \\
$\mathrm{p}_{1}(10 \mathrm{ml} / \mathrm{l})$ & $5,48 \mathrm{a}$ & $6,35 \mathrm{a}$ & $7,40 \mathrm{a}$ \\
$\mathrm{p}_{2}(20 \mathrm{ml} / \mathrm{l})$ & $5,48 \mathrm{a}$ & $6,40 \mathrm{a}$ & $7,33 \mathrm{a}$ \\
$\mathrm{p}_{3}(30 \mathrm{ml} / \mathrm{l})$ & & & \\
& & & \\
\hline Dosis Kalium & $5,58 \mathrm{a}$ & $6,43 \mathrm{a}$ & $7,20 \mathrm{a}$ \\
$\mathrm{k}_{0}($ Kontrol) & $5,50 \mathrm{a}$ & $6,35 \mathrm{a}$ & $7,43 \mathrm{a}$ \\
$\mathrm{k}_{1}(50 \mathrm{~kg} / \mathrm{ha})$ & $5,43 \mathrm{a}$ & $6,28 \mathrm{a}$ & $7,55 \mathrm{a}$ \\
$\mathrm{k}_{2}(75 \mathrm{~kg} / \mathrm{ha})$ & $5,40 \mathrm{a}$ & $6,43 \mathrm{a}$ & $7,53 \mathrm{a}$ \\
$\mathrm{k}_{3}(100 \mathrm{~kg} / \mathrm{ha})$ & &
\end{tabular}

Keterangan: Angka rata-rata pada kolom yang ditandai dengan huruf yang sama menunjukkan tidak berbeda nyata menurut Uji Jarak Berganda Duncan pada taraf nyata $5 \%$.

Hasil analisis ragam menunjukkan perlakuan dosis kalium tidak berbeda nyata pada berbagai taraf. Hal ini sejalan dengan hasil analisis ragam tinggi tanaman. Luas daun merupakan pertumbuhan vegetatif dan kurang berpengaruh pada pemberian pupuk kalium sehingga pemberian pupuk kalium pda berbagai taraf perlakuan tidak menunjukkan berbeda nyata. Kalium, merupakan logam bewarna putih keperakan dan tidak terdapat bebas di alam, unsur ini berperan penting dalam mengatur proses metabolisme, menguatkan jaringan batang dan meningkatkan resistensi hama penyakit (Ruhnayat, 1995). 


\section{Luas Daun $\left(\mathrm{cm}^{2}\right)$}

Hasil analisis ragam menunjukkan tidak terjadi interaksi antara dosis PGPR dan dosis kalium terhadap rata-rata luas daun tanaman jagung, dan secara mandiri juga tidak memberikan pengaruh yang nyata. Rata-rata luas daun tanaman dapat dilihat pada Tabel 3 .

Tabel 3. Pengaruh Konsentrasi PGPR dan dosis pupuk Kalium terhadap Luas Daun

\begin{tabular}{lc} 
Perlakuan & Luas Daun $\left(\mathbf{c m}^{2}\right)$ \\
\hline Dosis PGPR & \\
$\mathrm{p}_{0}(\mathrm{kontrol})$ & $313,71 \mathrm{a}$ \\
$\mathrm{p}_{1}(10 \mathrm{ml} / \mathrm{l})$ & $373,71 \mathrm{a}$ \\
$\mathrm{p}_{2}(20 \mathrm{ml} / \mathrm{l})$ & $368,96 \mathrm{a}$ \\
$\mathrm{p}_{3}(30 \mathrm{ml} / \mathrm{l})$ & $362,50 \mathrm{a}$ \\
\hline Dosis Kalium & \\
$\mathrm{k}_{0}(\mathrm{Kontrol})$ & $352,34 \mathrm{a}$ \\
$\mathrm{k}_{1}(50 \mathrm{~kg} / \mathrm{ha})$ & $343,79 \mathrm{a}$ \\
$\mathrm{k}_{2}(75 \mathrm{~kg} / \mathrm{ha})$ & $353,17 \mathrm{a}$ \\
$\mathrm{k}_{3}(100 \mathrm{~kg} / \mathrm{ha})$ & $369,58 \mathrm{a}$ \\
\hline
\end{tabular}

Keterangan: Angka rata-rata pada kolom yang ditandai dengan huruf yang sama menunjukkan tidak berbeda nyata menurut Uji Jarak Berganda Duncan pada taraf nyata $5 \%$.

Hasil analisis ragam dosis PGPR menunjukkan tidak berbeda nyata pada berbagai taraf perlakuan. Hal ini sejalan dengan hasil analisis ragam pada tinggi tanaman dan jumlah daun. Pertumbuhan luas daun, tinggi tanaman dan jumlah daun merupakan pertumbuhan vegetatif dan memiliki faktor pembatas yaitu sifat genetik tanaman. Pemberian pupuk penunjang pertumbuhan vegetatif yang sudah maksimal diserap oleh tanaman tidak bisa melebihi sifat genetik tanaman yang menjadi faktor pembatas, sehingga pemberian PGPR yang bisa memacu penyerapan unsur hara menjadi tidak berbeda nyata.

Hasil analisis ragam menunjukkan perlakuan dosis kalium tidak berbeda nyata pada berbagai taraf. Hal ini sejalan dengan hasil analisis ragam tinggi tanaman dan jumlah daun. Pupuk kalium pada pertumbuhan vegetatif kebutuhannya tidak sebanyak pupuk nitrogen. Nitrogen yang lebih berperan sehingga pemberian pupuk kalium pada berbagai dosis tidak berbeda nyata. Kalium diserap oleh tanaman dalam bentuk $\mathrm{K}^{+}$. Menurut Novizan (2002) Unsur K bagi tanaman berperan dalam translokasi gula pada pembentukan pati dan protein, membantu proses membuka dan menutup stomata, memperluas pertumbuhan akar, meningkatkan ketahanan tanaman terhadap serangan hama dan penyakit, dan memperbaiki ukuran seta kualitas buah pada fase generatif.

\section{Bobot Tongkol per Plot tanpa Kelobot (kg)}

Hasil analisis ragam menunjukkan tidak terjadi interaksi antara dosis PGPR dan dosis kalium terhadap rata-rata bobot bobot tongkol per plot, dan secara mandiri 
juga tidak memberikan pengaruh yang berbeda nyata. Bobot tongkol per plot dapat dilihat pada Tabel 4.

Tabel 4. Pengaruh Konsentrasi PGPR dan dosis pupuk Kalium terhadap Bobot Tongkol per Plot.

Perlakuan

\begin{tabular}{l}
\hline Dosis PGPR \\
$\mathrm{p}_{0}$ (kontrol) \\
$\mathrm{p}_{1}(10 \mathrm{ml} / \mathrm{l})$ \\
$\mathrm{p}_{2}(20 \mathrm{ml} / \mathrm{l})$ \\
$\mathrm{p}_{3}(30 \mathrm{ml} / \mathrm{l})$
\end{tabular}

Dosis Kalium

$\mathrm{k}_{0}$ (Kontrol)

$\mathrm{k}_{1}(50 \mathrm{~kg} / \mathrm{ha})$

$\mathrm{k}_{2}(75 \mathrm{~kg} / \mathrm{ha})$

$\mathrm{k}_{3}(100 \mathrm{~kg} / \mathrm{ha})$
Bobot Tongkol per Plot $(\mathbf{k g})$
3,83 a

3,82 a

3,90 a

3,85 a

Keterangan: Angka rata-rata pada kolom yang ditandai dengan huruf yang sama menunjukkan tidak berbeda nyata menurut Uji Jarak Berganda Duncan pada taraf nyata $5 \%$.

Hasil analisis ragam menunjukkan tidak berbeda nyata pada berbagai perlakuan dan taraf faktor dosis PGPR dan dosis kalium. Hal ini sejalan dengan hasil analisis ragam panjang tongkol dan bobot tongkol pertanaman. Diduga kandungan unsur hara pada tanah sudah sangat tinggi akibat dari akumulasi kandungan unsur pada tanah yang sudah ada dan pupuk dasar sehingga penambahan unsur hara pada tanah tidak berdampak apa-apa untuk penambahan nutrisi pada tanaman. Beberapa faktor yang mempengaruhi ketersediaan hara dalam tanah untuk dapat diserap tanaman antara lain adalah total pasokan hara, kelembaban tanah dan aerasi, suhu tanah, dan sifat fisik maupun kimia tanah. Keseluruhan faktor ini berlaku umum untuk setiap unsur hara (Olson and Sander 1988). Tanggapan tanaman terhadap pupuk bergantung pada jenis pupuk dan tingkat kesuburan tanah. Karena itu, takaran pupuk berbeda untuk setiap lokasi dan pada lokasi penelitian yang sudah banyak akumulasi unsur hara menyebabkan tidak berbeda nyata.

\section{Kualitas Tongkol}

Hasil analsis ragam menunjukkan tidak berbeda nyata antara pada perlakuan dosis PGPR dan dosis kalium pada berbagai taraf perlakuan. Hal ini sejalan dengan hasil analisis ragam panjang tongkol, bobot tongkol, dan hasil analisisis bobot perplot. Diduga persamaan ini akibat dari nilai akumulasi hara terkandung pada tanah yang sudah sangat tinggi yang menyebabkan pertambahan pupuk tidak memberikan pengaruh yang yang nyata. Karakter pertumbuhan tanaman dan hasil dipengaruhi oleh kesuburan lahan dan pemupukan (Tustiyani dkk, 2014) 
Pengelolaan hara spesifik lokasi (tergantung kandungan hara tanah) merupakan suatu upaya untuk mewujudkan penyediaan hara bagi tanaman, baik jumlah maupun waktu yang mempertimbangkan kebutuhan hara tanaman, kondisi lahan atau kapasitas dalam menyediakan hara bagi tanaman (Makarim et al., 2003) apabila kandungan hara sudah mencukupi untuk pertumbuhan dan perkembangan tanaman, penambahan pupuk yang diberikan menjadi kurang efektif dan tidak efisien.

Tabel 5. Pengaruh Konsentrasi PGPR dan dosis pupuk Kalium terhadap Kualitas Tongkol per Plot

\begin{tabular}{lccc}
\hline \multirow{2}{*}{ Perlakuan } & \multicolumn{3}{c}{ Kualitas Tongkol per plot $(K g)$} \\
\cline { 2 - 4 } & Kualitas A & Kualitas B & Kualitas C \\
\hline Dosis PGPR & $1,36 \mathrm{a}$ & $1,92 \mathrm{a}$ & $0,57 \mathrm{a}$ \\
$\mathrm{p}_{0}(\mathrm{kontrol})$ & $1,34 \mathrm{a}$ & $1,91 \mathrm{a}$ & $0,57 \mathrm{a}$ \\
$\mathrm{p}_{1}(10 \mathrm{ml} / \mathrm{l})$ & $1,36 \mathrm{a}$ & $1,95 \mathrm{a}$ & $0,58 \mathrm{a}$ \\
$\mathrm{p}_{2}(20 \mathrm{ml} / \mathrm{l})$ & $1,35 \mathrm{a}$ & $1,93 \mathrm{a}$ & $0,58 \mathrm{a}$ \\
$\mathrm{p}_{3}(30 \mathrm{ml} / \mathrm{l})$ & $1,34 \mathrm{a}$ & $1,92 \mathrm{a}$ & $0,58 \mathrm{a}$ \\
& $1,34 \mathrm{a}$ & $1,89 \mathrm{a}$ & $0,56 \mathrm{a}$ \\
\hline Dosis Kalium & $1,37 \mathrm{a}$ & $1,96 \mathrm{a}$ & $0,59 \mathrm{a}$ \\
$\mathrm{k}_{0}(\mathrm{Kontrol})$ & $1,36 \mathrm{a}$ & $1,94 \mathrm{a}$ & $0,58 \mathrm{a}$ \\
$\mathrm{k}_{1}(50 \mathrm{~kg} / \mathrm{ha})$ & $\mathrm{k}_{2}(75 \mathrm{~kg} / \mathrm{ha})$ & $\mathrm{k}$ & \\
$\mathrm{k}_{3}(100 \mathrm{~kg} / \mathrm{ha})$ & & & \\
\hline
\end{tabular}

Keterangan: Angka rata-rata pada kolom yang sama ditandai dengan huruf yang sama menunjukkan tidak berbeda nyata menurut Uji Jarak Berganda Duncan pada taraf nyata $5 \%$.

\section{KESIMPULAN DAN SARAN}

\section{Kesimpulan}

Berdasarkan hasil penelitian mengenai pertumbuhan dan hasil jagung manis pada perlakuan berbagai konsentrasi PGPR dan dosis pupuk kalium dapat disimpulkan sebagai berikut :

1. Secara mandiri konsentrasi PGPR dan dosis kalium tidak memberikan pengaruh yang nyata terhadap pertumbuhan dan hasil jagung manis.

2. Tidak terjadi interaksi antara berbagai konsentrasi PGPR dan dosis pupuk kalium terhadap pertumbuhan dan hasil jagung manis.

\section{Saran}

Dari kesimpulan di atas penulis dapat memberikan masukan berupan saran untuk melakukan penelitian lain dengan perlakuan konsentrasi dan dosis yang berbeda pada komoditi yang sama di tempat dan situasi yang berbeda. 


\section{DAFTAR PUSTAKA}

Badan Pusat Statistik. 2018. Produksi Jagung Menurut Provinsi (Ton). Http://Bps.Go.Id. Diakses Pada Desember 2018.

Fitrah P. 2017. Pengaruh Pemberian Plant Growth Promoting Rhizobakteria (Pgpr) Dari Akar Bambu Terhadap Pertumbuhan Dan Hasil Bawang Merah (Allium Ascalonicum L.). Jurnal Agrotropika Hayati 4(2): 77-83

Iskandar, D., 2007. Pengaruh Dosis Pupuk N, P Dan K Terhadap Pertumbuhan Dan Produksi Tanaman Jagung Manis Di Lahan Kering. Http://Www.Iptek.Net.Id. [17 Desember 2018]

Makarim, A, Widiarta I, Hendarsih S, Abdurachman S. 2003. Panduan Teknis Pengelolaan Hara Dan Pengendalian Hama Penyakit Tanaman Padi Secara Terpadu. Puslitbang Tanaman Pangan. Bogor. 37p

Novizan. 2002. Petunjuk Pemupukan Yang Efektif. Jakarta : Agromedia Pustaka

Olson, R.A. And D.H. Sander. 1988. Corn Production. In Monograph Agronomy Corn And Corn Improvement. Wisconsin. P.639-686.

Prahasta, 2009. Agribisnis Jagung, Penerbit Cv. Pustaka Grafika Bandung

Putri, A.A.P., Et Al. 2013. Pengaruh Plant Growth Promoting Rhizobacteria (Pgpr) Terhadap Infeksi Soybean Mosaic Virus (Smv), Pertumbuhan Dan Produksi Pada Tanaman Kedelai (Glycine Max (L.) Merr.) Varietas Wilis. Jurnal Hpt : Universitas Brawijaya

Ruhnayat, A. 1995. Peranan Unsur Hara Kaliumdalam Meningkatkanpertumbuhan Hasil Dan Daya Tahan Tanaman Rempah Dan Obat.Jurnalpenelitian Dan Pengembangan Pertanian, 14 (1): 201-211.

Saharan, B.S. And V. Nehra. 2011. Plant Growth Promoting Rhizobacteria : A Critical Review. Life Sciences And Medicine Reseacrh $21: 1$ - 30.

Saraswati, R. Dan Sumarno. 2008. Pemanfaatan Mikroba Penyubur Tanah Sebagai Komponen Teknologi Pertanian. Bogor.

Shaila, G. A. Tauhid, I. Tustiyani. 2019. Pengaruh Dosis Urea Dan Pupuk Organik Cair Asam Humat Terhadap Pertumbuhan Dan Hasil Tanaman Jagung Manis. Jurnal Agritop 17 (1): 35-44.

Tustiyani, I., Sugiyanta, M Melati. 2014. Karakter Morfofisiologi dan Fisikokimia Beras dengan Berbagai Dosis Pemupukan Organik dan Hayati pada Budidaya Padi Organik. J. Agron. Indonesia 42 (3) : 187 - 194

Wibowo A.S., Barunawati N., Maghfoer M.D. 2017. Respons Hasil Tanaman Jagung Manis (Zae mays L. Saccaharata) terhadap Pemberian KCl dan Pupuk Kotoran Ayam. Fakultas Pertanian Universitas Brawijaya. Malang. 